\title{
Capsular Invasion
}

National Cancer Institute

\section{Source}

National Cancer Institute. Capsular Invasion. NCI Thesaurus. Code C46128.

A microscopic finding indicating the infiltration of the capsule that surrounds an organ by a malignant cellular population. 